\title{
Prospects for achieving the Sustainable Development Goals 2030 Through A Proposed Halal Entrepreneurship Success Index (HESI)
}

\author{
Mohamed Salaheldeen ${ }^{1}$ *, Mohamed Battour ${ }^{2}$, Muhamad Azrin Nazri ${ }^{3}$, and Ummi Salwa \\ Ahmad Bustamam ${ }^{3}$ \\ ${ }^{1}$ Faculty of Economics and Muamalat, Universiti Sains Islam Malaysia (USIM), Malaysia and, \\ Faculty of Commerce, Menoufia University, Egypt. \\ ${ }^{2}$ Faculty of leadership and management, Universiti Sains Islam Malaysia (USIM), Malaysia and, \\ University of Sharjah, Sharjah, UAE. \\ ${ }^{3}$ Faculty of Economics and Muamalat, Universiti Sains Islam Malaysia (USIM), Malaysia.
}

\begin{abstract}
The Global Islamic Economy Indicator recognizes Malaysia as a global leader of the Islamic/Halal economy. Malaysia is also expanding its Islamic Economy and Business Ecosystem. Accordingly, the Ministry of Entrepreneur Development (MED) in Malaysia aims to produce a million small and medium enterprise (SME) entrepreneurs in 2019-2023. However, the Global Innovation Index in 2018 and 2019 ranked Malaysia in the 35th place globally, behind top Asian innovators like Singapore, South Korea, and Japan. This raises an important question: How can Malaysia foster its entrepreneurial economy using its advantageous position in the Halal industry? Malaysia must act now to prepare for a future led by innovation and technology. The country can use the Halal Entrepreneurship Success Scale to foster sustainable innovation and achieve the Sustainable Development Goals (SDGs). Measuring the success of Halal entrepreneurs in Malaysia can help it to achieve the SDGs. The religious background of Halal entrepreneurs motivates them to contribute positively to their society and environment. Halal entrepreneurship can be a driver of transformation that can help attain and deliver the SDGs while promoting sustainable economic growth. The findings of this paper can be useful to policy makers, regulators, practitioners, and academics.
\end{abstract}

\section{Introduction}

The relationship between entrepreneurship and sustainable development is positive in the presence of a high level of innovation (Youssef, Boubaker, \& Omri, 2018). Researchers are increasingly interested in examining the relationship between entrepreneurship and sustainable innovation (Salaheldeen, 2017; Schaltegger, Beckmann, \& Hockerts, 2018).

* Corresponding author: salaheldeen@raudah.usim.edu.my 
The contribution of sustainable entrepreneurship towards the entrepreneurial economy is a complex process that requires more research (HA \& HOA, 2018). Previous studies recommended identifying the characteristics of sustainability-oriented entrepreneurship visà-vis conventional entrepreneurship and examining the motivations of sustainabilityoriented entrepreneurs (Salindal, 2018).

Research on how to foster sustainable innovation in the global Halal industry in general, and the Malaysian Halal industry in particular, is scarce (Noureldeen, Salaheldeen, \& Battour, 2022). Malaysia ranked 35th in the Global Innovation Index 2018 and 2019, and was not among the top innovators in Asia (they were Singapore, South Korea, and Japan). This raises two important questions: Why did Malaysia not rank in the top 10 of the Index? How can Malaysia foster its entrepreneurial economy using its advantageous position in the global Halal industry? Malaysia must act now to prepare for a future led by innovation and technology. The country can use the Halal Entrepreneurship Success Index (HESI) to foster sustainable innovation, achieve the Sustainable Development Goals (SDGs), and become one of the top global innovators. Therefore, the objective of this study is to develop a conceptual framework to fill this gap in the entrepreneurship literature. The findings of this study can be useful to policy makers, regulators, practitioners, and entrepreneurs in the Halal industry.

\section{Halal Entrepreneurship}

Entrepreneurship from the Islamic perspective is a challenging concept (Battour, Salaheldeen, \& Mady, 2021). Islamic entrepreneurship is founded on three interlinking pillars of entrepreneurial, religious-spiritual, and socioeconomic/ethical (Ramadani, Dana, Ratten, \& Tahiri, 2015). It differs from ethical entrepreneurship due to its well-defined practices, scriptural sources, and distinct meta-physical objective (Gümüsay, 2015). Islamic entrepreneurship also affects both micro and macro levels of analysis in multidimensional ways, as it shapes the organization, individual, and institution, e.g., market and state (Khalek, 2018; Salaheldeen, Battour, \& Nazri, 2019). Halal entrepreneurship is, therefore, thoroughly complex, and so it must be integrated into holistic models that are explanatory rich yet parsimonious.

Halal entrepreneurship has significantly increased in Malaysia. In accordance with this trend, in 2015, Malaysia became the leading country in the global Halal Food Indicator, ahead of the United Arab Emirates and Australia (Zakaria \& Kaushal, 2017). The emergence of Halal entrepreneurship was accompanied by Halal food, which was soon followed by other segments such as cosmetics, personal care, pharmaceuticals, tourism, hospitality, logistics, and banking (Battour, Salaheldeen, Mady, \& Elsotouhy, 2021). Therefore, Halal entrepreneurs are growing rapidly in almost every industry.

Islamic practices and values significantly influence entrepreneurial intentions (Rehan, Block, \& Fisch, 2019). The ethical values inherent in Islam are the basis for the Islamic/Halal economy. Malaysia is considered as a leader in the Islamic/Halal economy. Halal food and ingredients are frequently mentioned together in the Quran. Dr. Umar Chapra, the Islamic economist, said, "Two of the most important constituents of maqasid al-Shariah (objectives of Shariah) are socioeconomic justice and the well-being of all God's creatures" (Chapra, 1993). Consequently, the Islamic/Halal economy has earned the preference of customers and entrepreneurs. Muslim/Halal entrepreneurs, business leaders, and customers whose identity centers around Islam are increasingly participating in Islamic business as a means of religious and social empowerment (Boubekeur, 2016). 
The Islamic entrepreneurship model does not solely aim for pecuniary gains, but it also strives towards social and religious goals (Salaheldeen et al., 2019). Entrepreneurship, particularly when perceived from an Islamic ontology, is "a social process that is embedded in different scopes outside the purview of what is generally conceived as the purely economic scope" (Tok \& Kaminski, 2018). Therefore, the success of Halal entrepreneurs cannot be evaluated using only financial/economic indicators, but it must also be measured using social and religious indicators.

\section{Entrepreneurship Success Indicators}

Entrepreneurial success was solely measured with financial/economic indicators (Zhou, Zhou, Zhang, Obschonka, \& Silbereisen, 2019), for example growth, efficiency, market share, profits, and liquidity (Murphy, Trailer, \& Hill, 1996), firm size, earnings, survival probability (Fried \& Tauer, 2015), and the increase in the number of workers (Sullivan \& Meek, 2012). However, entrepreneurial success as perceived by entrepreneurs should include personal and macro level variables. Entrepreneurial success is a multidimensional construct that captures more than just financial/economic indicators (Fisher, Maritz, \& Lobo, 2014). A business that fulfils certain indicators of success may mean its failure if measured using other indicators (Davidsson, Steffens, \& Fitzsimmons, 2009).

An extended definition of success covers various measures that reflect the complex realities of entrepreneurs. Accordingly, the measures of success should consider these realities (Dej, 2010). Limiting entrepreneurial success to only economic/financial indicators cannot capture its full meaning (Wach, Stephan, \& Gorgievski, 2016). An entrepreneur who succeeds based on a given indicator may fail based on another (Davidsson et al., 2009). Entrepreneurs themselves define success using different criteria. Economists rely only on indicators of organizational performance, which are difficult to attain in entrepreneurial settings (Dej, 2010). Therefore, the Halal Entrepreneurship Success Index is developed to identify the success indicators of entrepreneurs in the Halal industry.

\section{The Halal Entrepreneurship Success Scale (HESS)}

According to Gümüsay (2015), the interlinking religious-spiritual, entrepreneurial, and socioeconomic/ethical pillars found Islamic entrepreneurship. Particularly when perceived from an Islamic ontology, Islamic entrepreneurship is a "social process that is embedded in different scopes outside the purview of what is generally conceived of as the purely economic scope" (Tok \& Kaminski, 2018). Islamic akhlaq values such as confidence, sincerity, truthfulness, harmony, and flexibility can increase the performance of firms and enhance their innovation capability (Mahfoudh, Din, \& Jusoh, 2016).

Despite being a global Halal hub, Malaysia was ranked 35th in the Global Innovation Index (Index, 2018). There is, therefore, urgency for an empirical tool that can map the success of entrepreneurs so as to foster innovation and SDGs. Theoretically, the HESS bridges the literature gap concerning the measurement of halal entrepreneurial success. HESS comprises four dimensions: religious success, economic success, social success, and environmental success (see Figure 1).

The religious success dimension can be identified through the Islamic attributes of Muslim entrepreneurs: honesty, wisdom, trust, sharing, hardworking, and avoiding interest (S. Abdullah \& Mikail, 2013). The economic success dimension comprises profit, owning a registered office, having employees, creating job positions, and financial liquidity (Staniewski \& Awruk, 2018). The social success dimension comprises the level of 
satisfaction with business development, number of clients, work-life balance of employees, personal expectations for their life and business, and workplace relations (Fisher et al., 2014). Finally, the environmental success dimension could be identified in terms of community impact, providing environmentally friendly services or products, and supporting society (Khalid, 2017; Salaheldeen, 2015).

Mixed methods (i.e., quantitative and qualitative) research can advance the entrepreneurship scholarship and tackle challenges of previous studies (Watson, 2013). Casson and Rose (1997, p. 6) argued that the broader study of institutional environment is inseparable from the study of businesses. Therefore, quantitative and qualitative methods were used to develop the HESS, an instrument to measure the success of halal entrepreneurs. In the first stage, qualitative methods allowed the researcher to capture and generate the items for the scale from the respondents. Then, quantitative data analysis was performed to confirm the qualitative findings and validate the HESS.

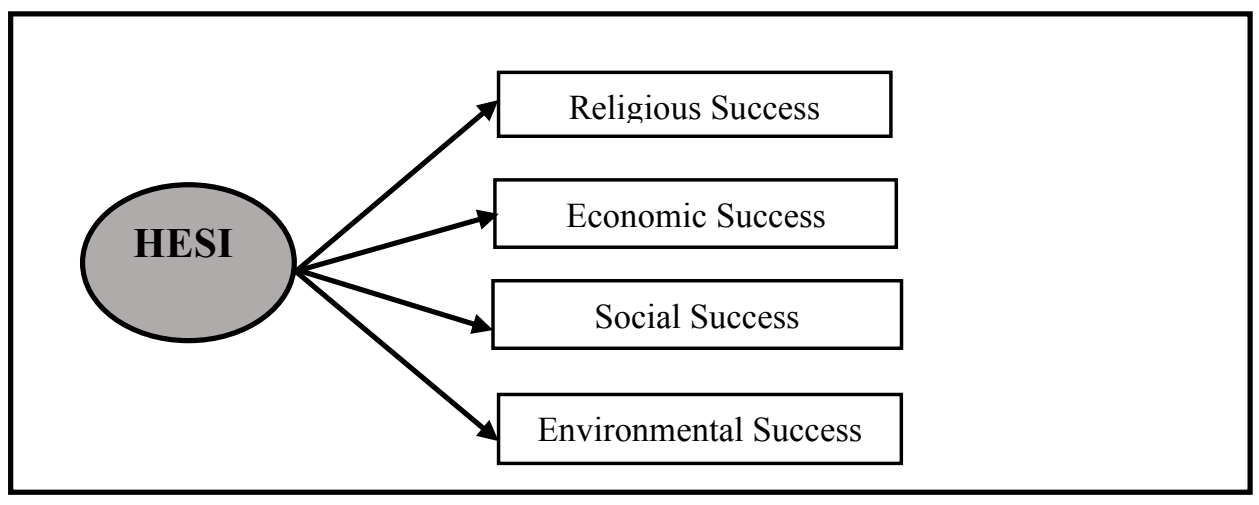

Fig. 1. Dimensions of the Halal Entrepreneurship Success Scale

\section{Halal Entrepreneurship and Sustainable Developments Goals 2030}

The pressing need for solutions against social and ecological problems around the world has firmly driven sustainable development into the political agenda (George, Howard-Grenville, Joshi, \& Tihanyi, 2016; Salaheldeen, 2015). The Sustainable Development Agenda 2030, which has been adopted by all members of the United Nations in 2015, provides a shared blueprint for the current and future peace and prosperity of mankind and the world. It comprises 17 SDGs that must be jointly accomplished by every developing and developed country.

Entrepreneurship can be a driver of transformation that can help attain and deliver the SDGs while promoting sustainable economic growth (Hossain, Saleh, \& Drennan, 2017). Entrepreneurs are more likely to discover the opportunities for sustainable development (Patzelt \& Shepherd, 2011). Rahdari, Sepasi, and Moradi (2016) highlighted the role of social enterprises for the accomplishment of the SDGs. The commitment of social entrepreneurs to social goals can lead them to exploit limited resources (Desa, 2012).

Sustainable development requires a society pool approach to innovation, which means that it must involve multiple stakeholders, e.g., government, employees, and trade partners. (Muñoz-Pascual, Curado, \& Galende, 2019). The European Union policy rhetoric articulates the meaning of entrepreneurship for sustainable development (Salmivaara \& Kibler, 2019). Scholars, industry professionals, and government representatives largely 
accept that innovation is a key driver for sustainability (Silvestre \& Ţîrcă, 2019). An entrepreneur is a person whose entrepreneurship cannot be removed from the general social setting (Bosma \& Kelley, 2019). The Amazon co-founder, Jeff Bezos, is an illustrative example of an entrepreneur. He revolutionizes the e-commerce space, transforming Amazon from a bookstore into the top e-retailer (Turban, King, Lee, Liang, \& Turban, 2015).

It is essential to identify the ethics underpinning the Halal/Islamic economy. The SDGs are an excellent reference point for the prioritization of benefits for the sectors of the Islamic economy, as they overlap with several maqasid al-Shariah and reflect the needs of the worldwide community (M. Abdullah, 2018). Figure 2 maps the SDG goals to the sectors of the Islamic/Halal economy (Reuters \& Standard, 2018). Entrepreneurship, particularly when perceived an Islamic ontology, is a social process that is embedded in different scopes outside the purview of what is generally conceived as the purely economic scope.

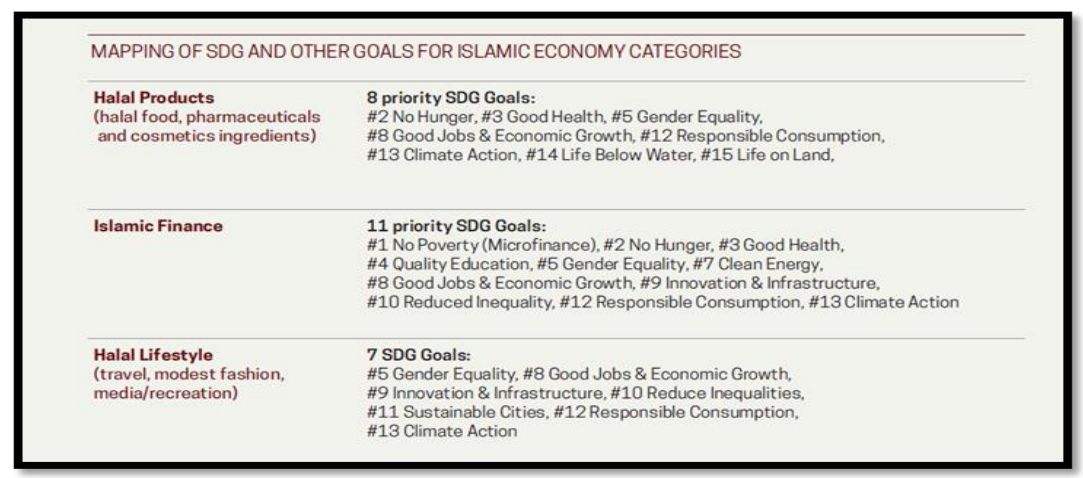

Fig.2. Mapping of SDG and other goals for Islamic economy categories. Source: State of the Global Islamic Economy Report 2018/19.

Malaysia promotes itself as a global Halal hub and currently leads the Global Islamic Economic Indicator. It continues to expand its Islamic Economy and Business Ecosystem (Reuters \& Standard, 2018). Malaysia has also launched the Social Enterprise Accreditation (SE.A), a national certification to recognize social enterprises and provide them with a means to communicate their commitments to social and environmental concerns. In its review, the Malaysian SDG report stated that the government maintains its support for entrepreneurs to achieve the SDGs by 2030 (Unit, 2017). Therefore, the HESS can be an essential reference for Halal entrepreneurs and policy makers and an indicator of the achievement of Islamic principles that complement the SDGs.

\section{Conclusion and implication}

The current study has discussed the relationship between Halal entrepreneurship and the SDGs. Halal entrepreneurs are more likely to discover and exploit sustainable development opportunities. Halal entrepreneurship has the potential to be a driver of sustainability, providing the framework to achieve and deliver the SDGs while promoting sustainable economic growth. Moreover, the HESS, which is founded on theories on Islamic entrepreneurship, sustainability, conventional entrepreneurship, and innovation, can fill the literature gap concerning the measurement of halal entrepreneurial success. It can 
also be an instrument by which halal entrepreneurs can foster innovation and achieve the SDGs. HESS comprises four interlinked dimensions: religious success, economic success, social success, and environmental success. The findings of this study suggest the potential of Halal entrepreneurship to contribute to the SDGs, seeing its objectives largely overlap the SDGs. Future research may test the HESS as a new scale. It is also recommended to relate the HESS to other variables for validation and further improvements. Finally, the findings of this study will help the stakeholders of the Halal industry to better understand Halal entrepreneurship and its impact on the SDGs.

\section{References}

Abdullah, M. (2018). Waqf, Sustainable Development Goals (SDGs) and maqasid alshariah. International Journal of Social Economics, 45(1), 158-172. doi:10.1108/IJSE-10-2016-0295

Abdullah, S., \& Mikail, S. (2013). Entrepreneurship and Islam: An expository study on characteristics of Muslim entrepreneur. Paper presented at the Proceeding of the 5th Islamic Economics System Conference: Sustainable Development Through The Islamic Economics System, Faculty Economics And Muamalat, Universiti Sains Islam Malaysia, Kuala Lumpur.

Battour, M., Salaheldeen, M., \& Mady, K. (2021). Halal tourism: exploring innovative marketing opportunities for entrepreneurs. Journal of Islamic Marketing, ahead-ofprint(ahead-of-print). doi:10.1108/JIMA-06-2020-0191

Battour, M., Salaheldeen, M., Mady, K., \& Elsotouhy, M. (2021). Halal Tourism: What Is Next For Sustainability? Journal of Islamic Tourism 1(Inaugural Issue ), 80-91.

Bosma, N., \& Kelley, D. (2019). Global Entrepreneurship Monitor 2018/2019 Global Report. Global Entrepreneurship Research Association (GERA).

Boubekeur, A. (2016). Islamic business and Muslim Entrepreneurs networks in Europe: performing transnational modernity and overcoming marginalization. Contemporary Islam, 10(3), 421-432.

Casson, M., \& Rose, M. B. (1997). Introduction, Institutions and Evolution of Modern Business. In: London: Frank Cass.

Chapra, M. U. (1993). Islam and economic development: A strategy for development with justice and stability (Vol. 14): International Institute of Islamic Thought (IIIT).

Davidsson, P., Steffens, P., \& Fitzsimmons, J. (2009). Growing profitable or growing from profits: putting the horse in front of the cart? Journal of Business Venturing, 24(4), 388-406.

Dej, D. (2010). Defining and measuring entrepreneurial success.

Desa, G. (2012). Resource mobilization in international social entrepreneurship: Bricolage as a mechanism of institutional transformation. Entrepreneurship Theory and Practice, 36(4), 727-751.

Fisher, R., Maritz, A., \& Lobo, A. (2014). Evaluating entrepreneurs' perception of success: Development of a measurement scale. International Journal of Entrepreneurial Behaviour \& Research, 20(5), 478-492.

Fried, H. O., \& Tauer, L. W. (2015). An entrepreneur performance index. Journal of Productivity Analysis, 44(1), 69-77.

George, G., Howard-Grenville, J., Joshi, A., \& Tihanyi, L. (2016). Understanding and Tackling Societal Grand Challenges through Management Research. Academy of Management Journal, 59(6), 1880-1895. doi:10.5465/amj.2016.4007

Gümüsay, A. A. (2015). Entrepreneurship from an Islamic perspective. Journal of Business Ethics, 130(1), 199-208. 
HA, N. T. T., \& HOA, L. B. (2018). EVALUATING ENTREPRENEURSHIP

PERFORMANCE IN VIETNAM THROUGH THE GLOBAL

ENTREPRENEURSHIP DEVELOPMENT INDEX APPROACH. Journal of

Developmental Entrepreneurship, 23(01), 1850006.

doi:10.1142/s1084946718500061

Hossain, S., Saleh, M. A., \& Drennan, J. (2017). A critical appraisal of the social entrepreneurship paradigm in an international setting: a proposed conceptual framework. International Entrepreneurship and Management Journal, 13(2), 347368.

Index, G. I. (2018). Energizing the world with innovation. URL: https://www. globalinnovationindex. org/gii-2017-report.

Khalek, A. A. (2018). Entrepreneurship and the Halal Wave in Malaysia. In Global Entrepreneurship and New Venture Creation in the Sharing Economy (pp. 191205): IGI Global.

Khalid, F. M. (2017). Exploring Environmental Ethics in Islam. The Wiley Blackwell Companion to Religion and Ecology, 130.

Mahfoudh, A., Din, M. S. H., \& Jusoh, M. S. (2016). The effect of Islamic work ethics (Akhlaq) to innovation capability. In Contemporary Issues and Development in the Global Halal Industry (pp. 381-390): Springer.

Muñoz-Pascual, L., Curado, C., \& Galende, J. (2019). The Triple Bottom Line on Sustainable Product Innovation Performance in SMEs: A Mixed Methods Approach. Sustainability, 11(6), 1689. Retrieved from https://www.mdpi.com/2071-1050/11/6/1689

Murphy, G. B., Trailer, J. W., \& Hill, R. C. (1996). Measuring performance in entrepreneurship research. Journal of Business Research, 36(1), 15-23. doi:https://doi.org/10.1016/0148-2963(95)00159-X

Noureldeen, A., Salaheldeen, M., \& Battour, M. (2022). Critical Success Factors for ERP Implementation: A Study on Mobile Telecommunication Companies in Egypt. In A.-S. M. A. Al-Emran M., Al-Kabi M.N., Shaalan K. (Ed.), International Conference on Emerging Technologies and Intelligent Systems (ICETIS) (Vol. 299, pp. 691-701). Cham: Springer

Patzelt, H., \& Shepherd, D. A. (2011). Recognizing Opportunities for Sustainable Development. Entrepreneurship Theory and Practice, 35(4), 631-652. doi:10.1111/j.1540-6520.2010.00386.x

Rahdari, A., Sepasi, S., \& Moradi, M. (2016). Achieving sustainability through Schumpeterian social entrepreneurship: The role of social enterprises. Journal of Cleaner Production, 137, 347-360.

Ramadani, V., Dana, L.-P., Ratten, V., \& Tahiri, S. (2015). The context of Islamic entrepreneurship and business: Concept, principles and perspectives. International Journal of Business and Globalisation, 15(3), 244-261.

Rehan, M., Block, J., \& Fisch, C. (2019). Entrepreneurship in Islamic Communities: How Do Islamic Values and Islamic Practices Influence Entrepreneurship Intentions? Journal of Enterprising Communities People and Places in the Global Economy. doi: $10.2139 /$ ssrn.3405196

Reuters, T., \& Standard, D. J. D. T. R. (2018). State of the global Islamic economy report 2018/19.

Salaheldeen, M. (2015). Management Control Systems as a Package: an application to Science \& Technology Parks: UPTEC Case Study. Paper presented at the 8th Conference On Performance Measurement And Management Control, Nice, France. 
Salaheldeen, M. (2017). Artificial Intelligence in Business Research: trends and future. Paper presented at the Emerging Issues and Challenges in Management Conference, Faculty of Commerce, Menoufia University, Egypt.

Salaheldeen, M., Battour, M., \& Nazri, M. A. (2019). Halal entrepreneurship and its role in sustainable development goals 2030 (SDGs). Paper presented at the International Conference on Dakwah and Islamic Management (IC-DAIM 2019) Malaysia.

Salindal, N. A. (2018). Halal certification compliance and its effects on companies' innovative and market performance. Journal of Islamic Marketing, 0(0), null. doi:10.1108/jima-04-2018-0080

Salmivaara, V., \& Kibler, E. (2019). "Rhetoric Mix" of Argumentations: How Policy Rhetoric Conveys Meaning of Entrepreneurship for Sustainable Development. Entrepreneurship Theory and Practice, 0(0), 1042258719845345. doi:10.1177/1042258719845345

Schaltegger, S., Beckmann, M., \& Hockerts, K. (2018). Collaborative entrepreneurship for sustainability. Creating solutions in light of the UN sustainable development goals. International Journal of Entrepreneurial Venturing, 10(2), 131-152.

Silvestre, B. S., \& Ţîrcă, D. M. (2019). Innovations for sustainable development: Moving toward a sustainable future. Journal of Cleaner Production, 208, 325-332. doi:https://doi.org/10.1016/j.jclepro.2018.09.244

Staniewski, M. W., \& Awruk, K. (2018). Questionnaire of entrepreneurial success-Report on the initial stage of method construction. Journal of Business Research, 88, 437442.

Sullivan, D. M., \& Meek, W. R. (2012). Gender and entrepreneurship: a review and process model. Journal of Managerial Psychology, 27(5), 428-458.

Tok, M. E., \& Kaminski, J. (2018). Islam, entrepreneurship, and embeddedness.

Turban, E., King, D., Lee, J., Liang, T.-P., \& Turban, D. (2015). Electronic Commerce Payment Systems. In Electronic Commerce (pp. 521-559): Springer International Publishing.

Unit, E. P. (2017). Malaysia sustainable development goals voluntary National review 2017. Retrieved on, 12.

Wach, D., Stephan, U., \& Gorgievski, M. (2016). More than money: Developing an integrative multi-factorial measure of entrepreneurial success. International Small Business Journal, 34(8), 1098-1121. doi:10.1177/0266242615608469

Watson, T. J. (2013). Entrepreneurial action and the Euro-American social science tradition: pragmatism, realism and looking beyond 'the entrepreneur'. Entrepreneurship \& Regional Development, 25(1-2), 16-33.

Youssef, A. B., Boubaker, S., \& Omri, A. (2018). Entrepreneurship and sustainability: The need for innovative and institutional solutions. Technological Forecasting and Social Change, 129, 232-241.

Zakaria, N., \& Kaushal, L. A. (2017). Global Entrepreneurship and New Venture Creation in the Sharing Economy: IGI global.

Zhou, M., Zhou, Y., Zhang, J., Obschonka, M., \& Silbereisen, R. K. (2019). Person-city personality fit and entrepreneurial success: An explorative study in China. International Journal of Psychology, 54(2), 155-163. doi:10.1002/ijop.12451 